\title{
Strategic Management of Small Enterprises in Commune of Peja
}

\author{
Ardian Berisha \\ PhD Cand. European University of Tirana \\ Samir Lleshi \\ PhD Cand. European University of Tirana
}

\begin{abstract}
This research is realized in city of Peja, a city in the western part of Republic of Kosovo. In this research are included 40 small enterprises (27 in the center of the city and 13 in the periphery). From them 37 enterprises were established from familiar-individual capital, whereas only three enterprises were corporations. This research is led from two correlation hypotheses. The first hypothesis of this research is:"Strategic management has a positive relation with the empowering of the short-term and long-term objectives of the small enterprises", is made correlative analysis and we have the statistical production [ $\left.r=.502^{* *}, p<.001\right]$, which supports the first hypothesis. Thus a genuine strategic management affects in the empowering and the reflection of the shortterm and long-term objectives of small enterprises. The second hypothesis of this research was;"Business strategy affects in the rise of financial indicators", is made the correlative analysis and we have this statistical production $[r=-.220, p<.172$, a result that is not significant and it does not support the second hypothesis of this research.
\end{abstract}

Keywords: Strategic, Management, Small, Enterprises, Commune, Peja

\section{Introduction}

The idea and the concept of this research was to see if there is a positive relation of strategic management with short-term and long-term objectives of the small enterprises and to see if the business strategy affects the raise of financial indicators. In the analyzed part of literature is cited for the management and especially for the strategic management. After raising of hypothesis and realization of the research methodology is concluded that strategic management is interrelated with the empowering of short-term and long-term objectives in the enterprise whereas the results of this research it did not result that business strategy affects in the raising of the financial indicators.

\section{Literature Reviews}

The word management derives from the word" to manage". In some languages for ex. French, Swedish, Albanian, SerboCroatian there is not an adequate unique meaning, which in general will correspond to the meaning of the word "manage". In most of the cases in this context are used terms: "governance", leadership", "direction" and similar like that. Native speakers in these countries for these terms borrow the foreign word "management". In Spanish the similar term is called "manejer" which means you are taught to do it, leads and governs directs you etc. Management in general meaning has these synonyms: placement, regulation, planning, inspection, direction, achievement of goals, realization, and also domination, rigging incurrence and deception. If we analyze all these synonyms we can conclude that these include: regulation, planning, inspection, organization, direction or realization. All of these have the meaning of one way process, the manager says to his "inferior" employees what should they work. Manager decides what to work, whereas those "under" (inferiors) are equipments to achieve a certain goal. They often call the manager" boss" whereas his assistant"the right hand", because the right hand does exactly what the head says. Managers are called supervisors, because is presupposed that supervisors have excellent views in certain situations (Ramosaj, 2007).

Many authors have studied the similarities between management and placement. The well known theoretician, especially of placement theory H.A. Simon uses the term placement as a synonym for the management. In fact, the author starts from it that the process of placement equalizes itself with the phase of making decisions, something according to the opinion of 
many authors is wrong, because the process of placement includes all the phases of placement and not just making decisions. We must have in mind that from the content that is understood with the term management, and also taking into consideration main functions of leadership is seen that it greatly fits with functions of management ,that means the terms management and leadership often are synonyms. So report between the management and placement is similar with the report between leadership and placement. Naturally we have to do with managerial placement and with managerial decisions. According to Akia Murrtiun making decisions respectively placement is the primary function of management .Whereas Yock Duncani states that if placement is not the only function of management, then it is surely its main function (Kuka, Shiroka-Pula \& Krasniqi, 2006).

Management is a process to fulfill the objectives with and through other people. This means you should be able to plan what must be done, to organize the material, means and equipments and also you should organize and lead people to perfect these goals. In general, there two extreme styles of management. Majority are somewhere in the middle. One of the extremes is dictatorial one. They are considered, autocratic managers, who use their authority to make decisions and then they order the others how to do that. The other extreme is known as "non-intervention" where the employees don't have the right to make decisions and to do their jobs, within determinations. Managing style depends from that how much you trust your employees and also from their abilities. Researchers have found that efficiency under the people leadership results from task combinations which must be done, type of employee, managers behaviors and from rewards structure (Mustafa, 2004).

Management shows a relatively universal activity because principles are applicable almost in all fields of economy and society: productivity, bank, trade, agriculture, sport, army, health religion, and international business etc. Also if we separate different organizations which are profitable or non-profit organizations or subjects and in the same time derives the question how to make them functional or how to govern and lead them, and then comes under consideration the request that what have in common and how are called all these people in these organizations from the different ones who deal with organizational work of these subjective. From this derives that these people are created with the name as managers, whereas their entire common activity is called management (Ramosaj, 2007).

What is strategic management? As an answer to the question submitted above, in the title of this text, we can say that after strategic management" hide" people who are obligated to plan the business in the highest level possible. Business-strategy as one of the highest functions in the enterprise is responsible to plan and to build a strong structure which will serve for overbuilding of business performances through additional activities (Biznesi.Info, 2012).

Strategic management initially has its origin from army strategies and as a process is transferred in the management of strategies in economy and then in non-profit organizations. The word "strategy" derives from the ancient Greek, in the years 507-508 before our era, where military council of Athens, consisted ten members which were called Strategoi, with great political and military power. In the semantic and origin aspect strategy is understood "ability to lead in the army" (Ancient Greek Encyclopedia "; mastery to direct something. Management of strategy in Western economy is used from 60 s of the twentieth (XX) century. In the US, in 1970, companies have implemented strategic management only $25 \%$, in the 80 s $55 \%$, in the 90 s $85 \%$ and from the year $2000100 \%$. This is an indicator that in the economical enterprises in the Republic of Kosovo, by all means should start not only to think for strategy but also to use the newest technologies of management until to the software managing process. Every period has its own characteristics of the development and the way how company behaves in such conditions. The switch of company from the concept as "closed system" to the "open system" especially the impact of the of suburb -external factors have conditioned the evolution of the problematic of longterm program. Today is implemented the strategic management to forecast the future. Strategic management is as a consequence of internationalization of the trade as a new form of the world trade that has impacted in the shortening of lifecycle of the company and exploiting cycle of products, whereas related with this also in the profit lifecycle (Mustafa, Kotorri, Krasniqi dhe Shala, 2010).

In the strategic aspect, management refers to the role of developing of the main objectives of activity and formulation of long-term plans for realization of these objectives. With the purpose of realization of the firm, management identifies stocks or strategies which should be undertaken and evaluated (Mustafa, 2008).

According to the all authors, strategic management is the permanent process of adjustment of the enterprise-surroundings, also its impact process in the suburb, in harmony with the goals of the company. Can be given definitions of different authors, but perhaps more summarizing is:"The process in which the management of the highest level (strategic leader) 
determines the direction of the long-term development of the company and its duties, by creating a strategy, its realization and permanent evaluation of realization, means that strategic management it is defined as a process which incorporates in years the goals of the company, formulation and the execution of the strategy and its control performance. According to Thompson and Striklend, in the process of the strategic management are foreseen five tasks: development (prosperity of strategic vision; determination of long-term goals; creation of the strategy and goals achievement; implementation and existence of strategy; the evolution of realization, review of new development and initiative of regulative corrections (Mustafa, Kotorri, Krasniqi dhe Shala, 2010).

The main characteristics of small enterprises are innovations .Small enterprise often is the source of new materials, of processes, ideas, services and products. Most of the products nowadays derive from small enterprises. Small enterprises have done more than the half of the inventions in the last 30 years. In the 80 s and 90 s small enterprises have made $80 \%$ of the employments of the new working places. The spreading of the small enterprises in Kosovo, by the dynamic can be seen in three phases: a) first phase from 1991 to 1993, b) second phase from 1994 to 2000 and c) third phase from the year 2001. The establishment of these enterprises hasn't been as a result of suitable environment of business, but it happened from the necessity to create new jobs for the people who were expelled from work. Small enterprises have characteristics which can be known easily: they are: flexibility-which means switching activities in the light of changes of the market conditions and the quick adjustment of the capacity of request; direct relationships during the work-the employer has intern relationships with his employees and customers: the possibility of employment; management from one person: independence during the management (Biznesi.Info, 2013).

\section{Hypothesis}

1."Strategic management has a positive connectivity with the strengthening of short-term and long-term objectives of the small enterprises.

2."Business strategy affects in the rise of financial indicators of small enterprises"

\section{METHODOLOGY}

\section{Participants}

This research is realized in city of Peja in the Republic of Kosovo, in this research are included 40 small enterprises (27 in the center) of the city and 13 in the periphery .From them 37 have been familiar-individual businesses whereas only 3 have been corporations. The meeting with the managers of these enterprises is realized in beginning of the June, in their objects where they do their business activity.

\section{Instrument}

From the type this research is quantitative and for the collection of the data is used a questionnaire with 27 questions which are mainly about goals, objectives and organization of the enterprise structure and managing strategies of the enterprises. The questionnaire has been simple and there were no open questions but only multiple questions and to each question the subjects have had the opportunity to circle only one from the offered alternatives.

\section{Procedure}

To realize this entire questionnaire it was necessary to collect quantitative data from field with the application of the questionnaires in enterprise. In each business object we have gone separately and it is contacted the manager of the enterprise and from him was required to fill in a questionnaire about the strategic management of enterprises. From the beginning are informed the managers that the questionnaire is anonymous and confidential, and then all of them have accepted to fill in the questionnaire. The data are elaborated with statistical program SPSS. 


\section{RESULTS}

Table 1: Correlation between strategic management and short-term and long-term objectives of the enterprises.

Correlations

\begin{tabular}{|c|c|c|c|}
\hline & & $\begin{array}{l}\text { Strategic management of } \\
\text { enterprises }\end{array}$ & $\begin{array}{l}\text { Short -term and long-term } \\
\text { objectives }\end{array}$ \\
\hline & Pearson Correlation & 1 & $.502^{\star *}$ \\
\hline & Sig. (2-tailed) & & .001 \\
\hline \multicolumn{4}{|l|}{ Strategic management of enterprises } \\
\hline & $\mathrm{N}$ & 40 & 40 \\
\hline & Pearson Correlation & $.502^{\star *}$ & 1 \\
\hline \multirow[t]{2}{*}{ Short -term and long-term objectives } & Sig. (2-tailed) & .001 & \\
\hline & $\mathrm{N}$ & 40 & 40 \\
\hline
\end{tabular}

${ }^{*}$. Correlation is significant at the 0.01 level (2-tailed).

To testify the first hypothesis of this research: Strategic management has a positive relation with the empowering of the short-term and long-term objectives of the small enterprises "

is made the correlative analysis and we have the statistical production. $\left[r=.502^{* *}, p<.001\right]$.

Table 2: Correlation between business strategies and financial indicators.

Correlations

\begin{tabular}{llll}
\hline & & $\begin{array}{l}\text { Business strategy and work } \\
\text { ethics }\end{array}$ & Financial indicators \\
\hline \multirow{2}{*}{ Business strategy and work ethics Sig. (2-tailed) } & 1 & -.220 \\
& Pearson Correlation & & .172 \\
& $\mathrm{~N}$ & 40 & 40 \\
Financial indicators & Pearson Correlation & -.220 & 1 \\
& Sig. (2-tailed) & .172 & \\
& $\mathrm{~N}$ & 40 & 40 \\
\hline
\end{tabular}

To testify the second hypothesis of this research;"Business strategy affects in the rise of the financial indicators of the small enterprises", is made the correlative analysis and we have the statistical production. [ $r=-.220, p<.172]$.

\section{Conclusions}

In this research is discussed relevant literature about what is understood with the word management, is cited for the strategic management for the small enterprises and business organizations .It is concluded that management is an ability to direct, to lead and to achieve certain goals. Regarding to the strategic management is understood that is as a guiding, as a plan which helps in the realization of the short-term and long-term objectives. Therefore for every enterprise small, middle, or big one, good management and especially strategic management are important components that every business enterprise should possess. Then are raised two hypotheses which have led this research, so let's see if they are supported. The first hypothesis of this research was:"Strategic management has a positive relation with the empowering of the shortterm and long-term objectives of the small enterprises", is made correlative analysis and we have the statistical production $\left[r=.502^{* *}, p<.001\right]$, which supports the first hypothesis. Thus a genuine strategic management affects in the empowering and the reflection of the short-term and long-term objectives of small enterprises.

The second hypothesis of this research was;"Business strategy affects in the rise of financial indicators", is made the correlative analysis and we have this statistical production $[r=-.220, p<.172$, a result that is not significant and does not support the second hypothesis of this research. 


\section{References}

[1] Kuka I. Shiroka-Pula J. Krasniqi B. Menaxhimi dhe vendosja. Prishtinë . 2006

[2] Mustafa I. Doracaku për krijimin dhe zhvillimin e bizneseve. IFK. Prishtinë. 2004

[3] Mustafa, I. Menaxhmenti financiar. Prishtinë. 2004

[4] Mustafa, N. Kotorri, M. Krasniqi, E. Shala, V. Menaxhmenti Strategjik. Prishtinë. 2010

[5] Ramosaj B. MANAGEMENT, Bazat e menaxhimit. Prishtinë. 2007

[6] Biznesi. Info, Çka është menaxhmenti strategjik? 2012

Questionnaire

\section{Your enterprise is:}

a)Familiar-individual business

b)Corporation

c)Business with limited responsibilities

2. In which area is your enterprise?

a) center

b) periphery

3. Which is your position in the organization where you work?
a) Executive chef or member of the highest team
management
b)Financial manager
c) Manager of Marketing and sales
d)Manager of production
e)Manager of human resources
f) Manager of lower level or supervisor
g)Other (please specify

4. How is organized the structure in your enterprise? Manager of the company
a) Yes
b) No

5. .How is organized the structure in your enterprise? Accounting
a) Yes
b) No

6. How is organized the structure in your enterprise? Purchasing manager
a) Yes
b) No

7. How is organized the structure in your enterprise? Sales manager
a) Yes
b) No

8. How is organized the structure in your enterprise? Human resources a) Yes

b) No

9. Short-term and long-term objectives? Sale of production
a) Yes
b) No

10. Short-term and long-term objectives? Quality of the product
a) Yes
b) No
11. Short-term and long-term objectives? Profitability
a) Yes
b) No

12. Short-term and long-term objectives? Survival
a) Yes
b) No
13. Short-term and long-term objectives? Social generality
a) Yes
b) No

14. Short-term and long-term objectives: moral of employees, and good relationships between them
a) Yes
b) No

15. What factors have encouraged you enterprise to choose the customers:
a) Demographic factors
b) Socio-economic factors
c) Psychological factors
d) Perceptual factors

16. Strategy of the cost leadership: Levels of competition 

a) Not at all
b) Very little
c) Little
d) Neutral
e) Moderately
f) Largely
g) In a large extent

17. Strategy of the cost leadership: Reduction of the cost product
a) Not at all
b) Very little
c) Little
d) Neutral
e) Moderately
f) Largely
g) In a large extent

18. Strategy of the cost leadership: Reduction of the additional costs
a) Not at all
b) Very little
c) Little
d) Neutral
e) Moderately
f) Largely
g) In a large extent

19. Aims of enterprise objectives: Earning increase
a) Very poorly
b)Poorly
c)Below average
d)Over average
e)Good
f) Very Good

20. Aims of enterprise objectives: Income increase
a) Very poorly
b)Poorly
c)Below average
d)Over average
e)Good
f)Very Good

21. Aims of enterprise objectives: Return in investments
a) Very poorly
b) Poorly
c) Below average
d) Over average
e)Good
f)Very Good

22. Aims of enterprise objectives: Cost reduction
a) Very poorly
b)Poorly
c) Below average
d)Over average
e)Good
f)Very Good

23. Aims of enterprise objectives: Improvement of the quality
a) Very poorly
b)Poorly
c) Below average
d) Over average
e)Good
f)Very Good

\section{Business strategy and work ethics}

a) The effect of the enterprise in your suburb

b) Work ethics and interpersonal relationships in the enterprise

c) The responsibility as base in the society in which we work

25. Financial indicators: Income
a) Medium
b) not important
c) Important
d) Very important

26. Financial indicators: Capital
a) Medium
b) Not important
c) Important
d) Very important

\section{Financial indicators: Profit}
a) Medium
b) Not important
c) Important
d) Very important 
Tables

1. Your enterprise is:

\begin{tabular}{|ll|r|r|r|c|}
\hline & Frequency & Percent & Valid Percent & Cumulative Percent \\
\hline \multirow{2}{*}{ Valid } & Familiar-individual business & 37 & 92.5 & 92.5 & 92.5 \\
& Corporation & 3 & 7.5 & 7.5 & 7.5 \\
& & & & & \\
& Total & 40 & 100.0 & 100.0 & 100.0 \\
\hline
\end{tabular}

2. In which area is your enterprise?

\begin{tabular}{|ll|l|l|l|l|}
\hline & Frequency & Percent & Valid Percent & Cumulative Percent \\
\hline \multirow{4}{*}{ Valid } & Center & 27 & 67.5 & 67.5 & 67.5 \\
& Periphery & 13 & 32.5 & 32.5 & 100.0 \\
& Total & 40 & 100.0 & 100.0 & \\
\hline
\end{tabular}

3. Which is your position in the organization where you work?

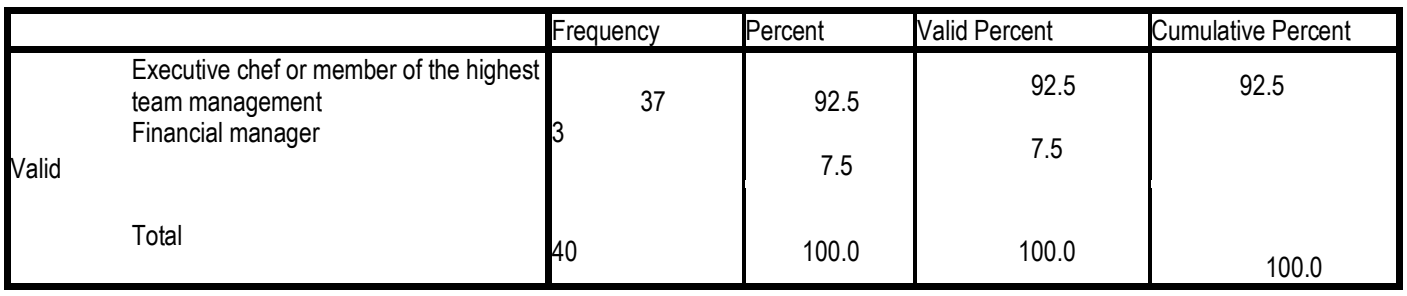

\section{How is organized the structure in your enterprise? Manager of the company}

\begin{tabular}{|l|l|l|l|l|}
\hline & Frequency & Percent & Valid Percent & Cumulative Percent \\
\hline Valid Yes & 40 & 100.0 & 100.0 & 100.0 \\
\hline
\end{tabular}

5. How is organized the structure in your enterprise? Accounting

\begin{tabular}{|ll|l|l|l|l|}
\hline & & Frequency & Percent & Valid Percent & Cumulative Percent \\
\hline \multirow{4}{*}{ Valid } & Yes & 38 & 95.0 & 95.0 & 95.0 \\
& No & 2 & 5.0 & 5.0 & 100.0 \\
& Total & 40 & 100.0 & 100.0 & \\
\hline
\end{tabular}

\section{How is organized the structure in your enterprise? Purchasing manager}

\begin{tabular}{|ll|l|l|l|l|}
\hline & & Frequency & Percent & Valid Percent & Cumulative Percent \\
\hline \multirow{4}{*}{ Valid } & Yes & 29 & 72.5 & 72.5 & 72.5 \\
& No & 11 & 27.5 & 27.5 & 100.0 \\
& Total & 40 & 100.0 & 100.0 & \\
\hline
\end{tabular}

7. How is organized the structure in your enterprise? Sales manager

\begin{tabular}{|ll|l|l|l|l|}
\hline & Frequency & Percent & Valid Percent & Cumulative Percent \\
\hline \multirow{4}{*}{ Valid } & Yes & 35 & 87.5 & 87.5 & 87.5 \\
& No & 5 & 12.5 & 12.5 & 100.0 \\
& Total & 40 & 100.0 & 100.0 & \\
\hline
\end{tabular}

\section{How is organized the structure in your enterprise? Human resources}




\begin{tabular}{|ll|l|l|l|l|}
\hline & & Frequency & Percent & Valid Percent & Cumulative Percent \\
\hline \multirow{3}{*}{ Valid } & Yes & 19 & 47.5 & 47.5 & 47.5 \\
& No & 21 & 52.5 & 52.5 & 100.0 \\
& Total & 40 & 100.0 & 100.0 & \\
\hline
\end{tabular}

9. Short-term and long-term objectives? Sale of production

\begin{tabular}{|ll|l|l|l|l|}
\hline & & Frequency & Percent & Valid Percent & Cumulative Percent \\
\hline \multirow{3}{*}{ Valid } & Yes & 37 & 92.5 & 92.5 & 92.5 \\
& No & 3 & 7.5 & 7.5 & 100.0 \\
& Total & 40 & 100.0 & 100.0 & \\
\hline
\end{tabular}

10. Short-term and long-term objectives? Quality of the product

\begin{tabular}{|ll|l|l|l|l|}
\hline & Frequency & Percent & Valid Percent & Cumulative Percent \\
\hline \multirow{4}{*}{ Valid } & Yes & 39 & 97.5 & 97.5 & 97.5 \\
& No & 1 & 2.5 & 2.5 & 100.0 \\
& Total & 40 & 100.0 & 100.0 & \\
\hline
\end{tabular}

11. Short-term and long-term objectives? Profitability

\begin{tabular}{|c|c|c|c|c|c|}
\hline & & Frequency & Percent & Valid Percent & Cumulative Percent \\
\hline Valid & Yes & 40 & 100.0 & 100.0 & 100.0 \\
\hline
\end{tabular}

12. Short-term and long-term objectives? Survival

\begin{tabular}{|ll|l|l|l|l|}
\hline & & Frequency & Percent & Valid Percent & Cumulative Percent \\
\hline \multirow{3}{*}{ Valid } & Yes & 24 & 60.0 & 60.0 & 60.0 \\
& No & 16 & 40.0 & 40.0 & 100.0 \\
& Total & 40 & 100.0 & 100.0 & \\
\hline
\end{tabular}

13. Short-term and long-term objectives? Social generality

\begin{tabular}{|l|l|l|l|l|}
\hline & Frequency & Percent & Valid Percent & Cumulative Percent \\
\hline Valid $\quad$ Yes & 40 & 100.0 & 100.0 & 100.0 \\
\hline
\end{tabular}

14. Short-term and long-term objectives: moral of employees, and good relationships between them

\begin{tabular}{|l|l|l|l|l|}
\hline & Frequency & Percent & Valid Percent & Cumulative Percent \\
\hline Valid Yes & 40 & 100.0 & 100.0 & 100.0 \\
\hline
\end{tabular}

15. What factors have encouraged you enterprise to choose the customers:

\begin{tabular}{|c|c|c|c|c|c|}
\hline & & Frequency & Percent & Valid Percent & Cumulative Percent \\
\hline Valid & $\begin{array}{l}\text { Demographic factors Socio-economic } \\
\text { factors } \\
\text { Psychological factors } \\
\text { Perceptual factors }\end{array}$ & $\begin{array}{l}15 \\
11 \\
2 \\
11\end{array}$ & $\begin{array}{c}37.5 \\
27.5 \\
5.0 \\
2.5\end{array}$ & $\begin{array}{l}37.5 \\
27.5 \\
5.0 \\
2.5\end{array}$ & $\begin{array}{l}37.5 \\
65.0 \\
70.0 \\
72.5\end{array}$ \\
\hline Total & & 40 & 100.0 & 100.0 & 100.0 \\
\hline
\end{tabular}


16. Strategy of the cost leadership: Levels of competition

\begin{tabular}{|ll|l|l|l|l|}
\hline & Frequency & Percent & Valid Percent & Cumulative Percent \\
\hline \multirow{5}{*}{ Not at all } & 1 & 2.5 & 2.5 & 2.5 \\
& Neutral & 5 & 12.5 & 12.5 & 15.0 \\
& Moderately & 6 & 15.0 & 15.0 & 30.0 \\
& Largely & 13 & 32.5 & 32.5 & 62.5 \\
& In a large extent & 15 & 37.5 & 37.5 & 100.0 \\
& Total & 40 & 100.0 & 100.0 & \\
\hline
\end{tabular}

17. Strategy of the cost leadership: Reduction of the cost product

\begin{tabular}{|ll|l|l|l|l|}
\hline & Frequency & Percent & Valid Percent & Cumulative Percent \\
\hline \multirow{3}{*}{ Valid } & Moderately & 10 & 25.0 & 25.0 & 25.0 \\
& Largely & 10 & 25.0 & 25.0 & 50.0 \\
& In a large extent & 20 & 50.0 & 50.0 & 100.0 \\
& Total & 40 & 100.0 & 100.0 & \\
\hline
\end{tabular}

18. Strategy of the cost leadership: Reduction of the additional costs

\begin{tabular}{|ll|l|l|l|l|}
\hline & Frequency & Percent & Valid Percent & Cumulative Percent \\
\hline \multirow{5}{*}{ Not at all } & 1 & 1 & 2.5 & 2.5 & 2.5 \\
Neutral & 1 & 2.5 & 2.5 & 5.0 \\
& Moderately & 8 & 20.0 & 20.0 & 25.0 \\
& Largely & 14 & 35.0 & 35.0 & 60.0 \\
& In a large extent & 16 & 40.0 & 40.0 & 100.0 \\
& Total & 40 & 100.0 & 100.0 & \\
\hline
\end{tabular}

19. Aims of enterprise objectives: Earning increase

\begin{tabular}{|ll|l|l|l|l|}
\hline & Frequency & Percent & Valid Percent & Cumulative Percent \\
\hline \multirow{4}{*}{ Valid } & Over average & 11 & 27.5 & 27.5 & 27.5 \\
& Good & 11 & 27.5 & 27.5 & 55.0 \\
& Very good & 18 & 45.0 & 45.0 & 100.0 \\
& Total & 40 & 100.0 & 100.0 & \\
\hline
\end{tabular}

20. Aims of enterprise objectives: Income increase

\begin{tabular}{|ll|l|l|l|l|}
\hline & Frequency & Percent & Valid Percent & Cumulative Percent \\
\hline \multirow{4}{*}{ Valid } & Over average & 4 & 10.0 & 10.0 & 10.0 \\
& Good & 18 & 45.0 & 45.0 & 55.0 \\
& Very good & 18 & 45.0 & 45.0 & 100.0 \\
& Total & 40 & 100.0 & 100.0 & \\
\hline
\end{tabular}

\section{Aims of enterprise objectives: Return in investments}

\begin{tabular}{|ll|l|l|l|l|}
\hline & & Frequency & Percent & Valid Percent & Cumulative Percent \\
\hline \multirow{4}{*}{ Valid } & Average & 1 & 2.5 & 2.5 & 2.5 \\
& Over average & 13 & 32.5 & 32.5 & 35.0 \\
& Good & 11 & 27.5 & 27.5 & 62.5 \\
& Very good & 15 & 37.5 & 37.5 & 100.0 \\
& Total & 40 & 100.0 & 100.0 & \\
\hline
\end{tabular}


22. Aims of enterprise objectives: Cost reduction

\begin{tabular}{|ll|l|l|l|l|}
\hline & Frequency & Percent & Valid Percent & Cumulative Percent \\
\hline \multirow{4}{*}{ Valid } & Poorly & 1 & 2.5 & 2.5 & 2.5 \\
& Average & 3 & 7.5 & 7.5 & 10.0 \\
& Over average & 14 & 35.0 & 35.0 & 45.0 \\
& Good & 5 & 12.5 & 12.5 & 57.5 \\
& Very good & 17 & 42.5 & 42.5 & 100.0 \\
Total & 40 & 100.0 & 100.0 & \\
\hline
\end{tabular}

\section{Aims of enterprise objectives: Improvement of the quality}

\begin{tabular}{|ll|l|l|l|l|}
\hline & & Frequency & Percent & Valid Percent & Cumulative Percent \\
\hline \multirow{4}{*}{ Valid } & Over average & 10 & 25.0 & 25.0 & 25.0 \\
& Good & 11 & 27.5 & 27.5 & 52.5 \\
& Very good & 19 & 47.5 & 47.5 & 100.0 \\
& Total & 40 & 100.0 & 100.0 & \\
\hline
\end{tabular}

24. Business strategy and work ethics

\begin{tabular}{|l|l|l|l|l|}
\hline & Frequency & Percent & Valid Percent & $\begin{array}{l}\text { Cumulative } \\
\text { Percent }\end{array}$ \\
\hline $\begin{array}{l}\text { Work ethics and interpersonal relationships } \\
\text { in the enterprise }\end{array}$ & 3 & 7.5 & 7.5 & 7.5 \\
$\begin{array}{l}\text { The responsibility as base in the society in } \\
\text { which we work }\end{array}$ & 37 & 92.5 & 92.5 & 100.0 \\
\hline Total & 40 & 100.0 & 100.0 & 100.0 \\
\hline
\end{tabular}

25. Financial indicators: Income

\begin{tabular}{|ll|l|l|l|l|}
\hline & Frequency & Percent & Valid Percent & Cumulative Percent \\
\hline \multirow{3}{*}{ Valid } & Important & 16 & 40.0 & 40.0 & 40.0 \\
& Very important & 24 & 60.0 & 60.0 & 100.0 \\
& Total & 40 & 100.0 & 100.0 & \\
\hline
\end{tabular}

\section{Financial indicators: Capital}

\begin{tabular}{|ll|l|l|l|l|}
\hline \multicolumn{2}{|c|}{ Important } & Frequency & Percent & Valid Percent & Cumulative Percent \\
\hline \multirow{3}{*}{ Valid } & 16 & 40.0 & 40.0 & 40.0 \\
& Very important & 24 & 60.0 & 60.0 & 100.0 \\
& Total & 40 & 100.0 & 100.0 & \\
\hline
\end{tabular}

\begin{tabular}{|c|c|c|c|c|c|}
\hline & & Frequency & Percent & Valid Percent & Cumulative Percent \\
\hline \multirow{3}{*}{ Valid } & Important & 22 & 55.0 & 55.0 & 55.0 \\
\hline & Very important & 18 & 45.0 & 45.0 & 100.0 \\
\hline & Total & 40 & 100.0 & 100.0 & \\
\hline
\end{tabular}

